\title{
BUREŠ, Jaroslav - ČEJKA, Marek - DANIEL, Jan. Muslimské bratrstvo v současnosti. Praha: Academia, 2017. ISBN 978-80-200-2670-5. 229 s.
}

\section{Daniel Svoboda}

Po útocích z 11. září se do popředí zájmu bezpečnostních i dalších expertů dostaly mnohé muslimské skupiny či organizace. V evropském kontextu tento fenomén zintenzivnil $v$ době migrační krize, která $v$ Evropě kulminovala v roce 2015. Tématem mnohých politiků, odborníků i laiků se staly domnělé i skutečné vazby islámských radikálů a teroristů na některé islámské organizace a jejich možný vliv na migrační krizi. Jednou $\mathrm{z}$ těchto organizací, které $\mathrm{v}$ rámci celé své dlouhé historie budily a i nadále budí vášně, je Muslimské bratrstvo. Tendence nahlížet na Muslimské bratrstvo jako na koherentní a jednolitou organizaci $z$ hlediska času i prostoru jsou ovšem značně zkreslující a problematické. Trojice Jaroslav Bureš, Marek Čejka a Jan Daniel se proto rozhodla pro analýzu frakcí Muslimského bratrstva v několika zemích, a to od jejich vzniku až po současnost, s důrazem na vývoj těchto lokálních frakcí po tzv. arabském jaru z přelomu let 2010 a 2011.

Publikace Muslimské bratrstvo v současnosti si tak klade za cíl přibližení proměn nejen ideologie, ale také konkrétní činnosti Muslimského bratrstva, resp. jeho vybraných lokálních odnoží, a to $v$ průběhu arabského jara a vobdobí po něm, které je charakterizováno jistým vychladnutím revolučních vášní. ${ }^{1}$ Trojice expertů na oblast MENA (MENA - Middle East and North Africa; Střední východ a severní Afrika) si pro svou analýzu Muslimského bratrstva, jehož kořeny sahají až do roku 1928 a u jehož zrodu stál jeden z nejvýznamnějších islámských učenců minulého století, Egypt'an Hassan alBanna, vybrala šest lokálních odnoží Muslimských bratří, a sice egyptskou, syrskou, palestinskou, jordánskou, tuniskou a marockou, přičemž každý autor zpracoval dvě prípadové studie. Ač na kapitolách autoři vzájemně spolupracovali, každá př́ípadová studie byla zpracována tak, že hlavní slovo v ní měl vždy konkrétní autor. Jaroslav Bureš analyzoval egyptské a syrské Muslimské bratrstvo, Marek Čejka na Muslimské bratrstvo odkazující palestinské hnutí Hamás a Muslimské bratry $v$ Jordánsku a Jan Daniel se zaměřil na severoafrické politické strany s odkazem na Ichwány ${ }^{2}$ - stranu an-Nahda $\checkmark$ Tunisku a Stranu rozvoje a spravedlnosti (PJD - Parti de la justice et du développement) $v$ Maroku. Jaroslav Bureš ještě nad rámec těchto př́padových studií přidává kapitolu se stručnými charakteristikami súdánského a jemenského (Isláh) Muslimského bratrstva a spolupráce Ichwánů s tureckou stranou AKP (Adalet ve Kalkınma

\footnotetext{
${ }^{a}$ Department of Politics and International Relations, University of West Bohemia. Pilsen, Czech Republic. svobodad@kap.zcu.cz. Researcher ID: F18P0005P-FF.

${ }^{1}$ Viz BUREŠ, Jaroslav - ČEJKA, Marek - DANIEL, Jan. Muslimské bratrstvo v současnosti. Praha: Academia, 2017, s. 21.

${ }^{2}$ Ichwáni je označení pro Muslimské bratry, ikhwan znamená arabsky bratři, popř. bratrstvo.
} 
Partisi - Strana spravedlnosti a rozvoje). Výběr zkoumaných zemí měl co nejlépe reflektovat specifika Muslimského bratrstva ve vztahu k různým autoritám či občanské společnosti konkrétních zemí.

Každá z šesti prípadových studií byla dále strukturována do tří částí, které měly každá odrážet určitou etapu vývoje Muslimského bratrstva - první část se zaměřovala na historický vývoj a kulturní ukotvení Muslimského bratrstva ve vybraných zemích, druhá část byla zaměřena na analýzu chování a činnosti Muslimského bratrstva během arabského jara a třetí část se zabývala poslední etapou vývoje Muslimského bratrstva, tedy obdobím následujícím po skončení revoluční fáze. Publikace nevychází z nějakého striktně daného teoretického ani metodologického rámce, byt' cíle, kritéria a zdůvodnění výběru zemí či opodstatnění výzkumu a výběru tématu jsou nastíněny v úvodu. Závěrem poté autoři shrnují dosažené poznatky, poukazují na zřejmé rozdíly mezi jednotlivými národními odnožemi a poznatky zasazují do celkového kontextu výzkumu.

Kniha tematicky zapadá do politicko-společenského diskurzu dnešní doby a vhodně přispívá do diskuze o islámském radikalismu. Bohužel ale panují značné rozdíly mezi jednotlivými kapitolami, a to jak z hlediska struktury a rozsahu, tak kvalitativně. Nejvíce problematicky pưsobí kapitoly s hlavním zpracováním Jaroslava Bureše. Kapitoly často působí jako nahodilý shluk dějinných faktů a historických událostí bez nějakého širšího ukotvení či zasazení do kontextu a text mnohdy pưsobí nepřehledně až zmateně. Autor uvádí velké množství arabských pojmů ${ }^{3}$ a termínů, které ale, bohužel, většinou nejsou vysvětleny nijak bliže, než jen doslovným překladem v závorce - pojmy se navíc často opakují, některé jsou vysvětlené víckrát a některé vůbec, občas se liší jejich arabský přepis. Jisté pasáže $v$ textu pưsobí silně arbitrárně a subjektivně, jako by vyjadřovaly spíše autorův názor, postoj či stanovisko k danému tématu než jeho objektivní a neutrální zhodnocení či popis. Jako příklad uved’me třeba kritiku odborné literatury, která označuje konzervativní křídlo Muslimských bratří z období arabského jara jako qutbisty ${ }^{4}$, ačkoliv podle autora měli mnohem bliže k Hasanu al-Hudajbímu toto tvrzení ovšem autor vydává za fakt, bez jakéhokoliv argumentu, důkazu či odkazu na jinou literaturu, navíc ani neuvádí, že je tomu tak podle něj ${ }^{5}$. Podobně tvrzení, že „Celkově byla ústava dost umírněná a málo revoluční"6. Autorova rétorika často pưsobí neodborně a zaujatě, jako by např. stranil Muslimskému bratrstvu a prezidentu Mursímu, a naopak kritizoval předchozí Mubárakův, a především současný Sísího režim. Pro odbornou publikaci se ovšem subjektivní a často ničím nepodložené názory autora nehodí. Dále stojí za zmínku občasné nejasné pojmy, které nemají v politické vědě ani príbuzných oborech žádnou jasnou definici a možná by stálo za to, aby je autor vysvětlil - viz např. „demokratické svobody“7. Některé věty nedávají smysl, nebo si vyloženě protiřečí, viz „Ženám a Koptům nebylo dovoleno kandidovat v prezidentských volbách,

\footnotetext{
${ }^{3}$ Problém přepisů z arabštiny se netýká jen arabských pojmů, ale také osobních jmen konkrétních osob. Některá jména pak téměř nejsou dohledatelná, jelikož není jasné, koho má autor na mysli. Např. v kapitole o Sýrii je krátce po sobě uvedeno jméno lídra MB dvěma různými variantami, ibid. s. 90-91.

${ }^{4}$ Stoupenci Sajjida Qutba.

${ }_{6}^{5}$ Ibid. s. 33.

${ }^{6}$ Ibid. s. 51.

${ }^{7}$ Ibid. s. 37.
} 
ačkoli jim byla přiznána plná občanská práva“8. Mezi základní občanská práva patří politická práva, tedy take volební právo pasivní, a sice být volen - pokud tedy ženy a Koptové v prezidentských volbách kandidovat nesměli, nebyla jim přiznána plná občanská práva. K větší přehlednosti a srozumitelnosti textu nepřispívá ani časté míchání pojmů, kdy autor jednou piše o generacích Ichwánů jako o konzervativcích a reformátorech, a poté jako o staré, střední a mladé generaci. Nikterak nerozporuji, že obě rozdělení jsou legitimní, avšak $v$ textu chybí detailnější vymezení toho, kdo tedy kam spadá a jak se tato rozdělení vzájemně doplňují. Nahodilé uvádění nejednotné terminologie poté ztěžuje orientaci mezi samotnými generačními rozděleními Ichwánů. Podobné nejasnosti, nepřehlednosti, názorově zabarvená tvrzení a subjektivní soudy se objevují také $v$ kapitole o Sýrii. Text proto často nepůsobí odborně, ale spíše publicisticky či populárně naučně, hlavně ale zaujatě.

Ostatní kapitoly trpí těmito problémy podstatně méně, navíc jsou také výrazně kratší oproti kapitolám věnujícím se Muslimským bratřím v Egyptě a Sýrii. I přes rozsahovou i obsahovou nevyváženost jednotlivých kapitol a problematičnost mnoha aspektů kapitol zabývajících se prvními dvěma zeměmi jsou mnohé informace a zjištění v této publikaci př́nosné. Publikace má spiše deskriptivní charakter a působí jako přehledová studie historického a současného vývoje vybraných odnoží Muslimského bratrstva, což samo o sobě rozhodně není na škodu. Publikace vhodně reflektuje podstatné odlišnosti fungování, zaměření i charakteru jednotlivých odnoží Muslimského bratrstva, které lze jen stěží chápat jako jednolitou a jednotně vystupující organizaci. Jednotlivé národní odnože Muslimských bratř́i se liší jak v důvodech, príčinách a pozadí jejich vzniku, tak $v$ jejich dalším vývoji, názorech a postojích $\mathrm{k}$ mnohým tématům, stejně jako ve vztazích s domácími i zahraničními aktéry, samotném významu a síle či míre zapojení do revolucí $z$ let 2011-2013 a jejich následném vývoji. Autorům se tedy na základě jejich studie vybraných odnoží Muslimského bratrstva podařilo prokázat značné odlišnosti mezi nimi, ba dokonce často také mezi frakcemi uvnitř samotných národních odnoží (nejvíce je toto patrné zejména $\vee$ Egyptě). Publikace tak může posloužit jako vhodný historický exkurz s přesahem do současnosti, který reflektuje odlišnosti $v$ rámci jednotlivých odnoží Muslimského bratrstva. Jako takový může být př́nosný odborníkủm z oblastí arabských, islámských či blízkovýchodních studií, politické vědy, mezinárodních vztahů či bezpečnostních studií, ale zejména také laikům či politikủm, kteři se k tomuto tématu, často neodborně a neobratně, vyjadřují. V současné atmosféře plné strachu a nedůvěry $z$ islámského náboženství a muslimských organizací, podezř́vaných (at' již oprávněně či nikoliv) z podpory extremismu a terorismu, je vice než potřeba dokázat se orientovat $\mathrm{v}$ samotné problematice a správně identifikovat a rozlišovat mezi islámskými reáliemi, které rozhodně nejsou černobílé. K lepšímu porozumění nejednotnosti a rozdílnosti konkrétně organizace Muslimské bratrstvo slouží právě tato publikace.

8 Ibid. s. 40-41. 